\title{
Producing public goods in the EU: European integration processes in the fields of refugee protection and climate stability
}

\section{Diego Caballero Vélez \& Marta Pachocka}

To cite this article: Diego Caballero Vélez \& Marta Pachocka (2020): Producing public goods in the EU: European integration processes in the fields of refugee protection and climate stability, European Politics and Society

To link to this article: https://doi.org/10.1080/23745118.2020.1791458

曲 Published online: 24 Jul 2020.

Submit your article to this journal $\pi$

Q View related articles $\sqsubset$

View Crossmark data $\nearrow$ 